\title{
Comparative longevity and age at sexual maturity in twelve rainforest frogs of the genera Boophis, Gephyromantis, and Mantidactylus (Anura: Mantellidae) from Madagascar
}

Giulia Tessa, ${ }^{1,2}$ Angelica Crottini, ${ }^{3}$ Cristina Giacoma, ${ }^{1}$ Fabio M. Guarino, ${ }^{4}$ Jasmin E. Randrianirina, ${ }^{5}$ and Franco Andreone ${ }^{2}$

${ }^{1}$ Dipartimento di Scienze della Vita e Biologia dei Sistemi, Università degli Studi di Torino, Via A. Albertina, 13, I-10123

Torino, Italy. E-mail: tessagiu@ @ibero.it.

${ }^{2}$ Museo Regionale di Scienze Naturali, Via G. Giolitti, 36, I-10123 Torino, Italy.

E-mail: franco.andreone@regione.piemonte.it.

${ }^{3}$ CIBIO, Research Centre in Biodiversity and Genetic Resources, InBIO, Universidade do Porto, Campus Agrário de Vairão, Rua Padre Armando Quintas 7, 4485-661, Vairão, Portugal. E-mail: tiliquait@yahoo.it.

${ }^{4}$ Dipartimento di Biologia, Università degli Studi di Napoli Federico II, Via Cinthia, I-80126 Napoli, Italy. E-mail: fabio.guarino@unina.it.

${ }_{5}^{5}$ Parc Botanique et Zoologique de Tsimbazaza, Département Faune, BP 4096, Antananarivo 101, Madagascar. E-mail: randrianirina_herpeto@yahoo.fr.

\begin{abstract}
Comparative longevity and age at sexual maturity in twelve rainforest frogs of the genera Boophis, Gephyromantis, and Mantidactylus (Anura: Mantellidae) from Madagascar. Data on the age at sexual maturity and longevity of some mantellid species of the genera Boophis, Gephyromantis, and Mantidactylus that inhabit the low altitude rainforest of Masoala (northeastern Madagascar) are presented. Counts of lines of arrested growth (LAGs) were used to calculate longevity in these species; these data contribute to assessment of the threat level of the studied anurans. Boophis includes species of mediumto large-sized frogs (SVL $=30-65 \mathrm{~mm}$ ) that attain sexual maturity in 1-3 years and live 3-9 years (i.e., mid-longevity). Mantidactylus and Gephyromatis include small- to largesized species ( $\mathrm{SVL}=22-107 \mathrm{~mm}$ and $35-49 \mathrm{~mm}$, respectively) that attain sexually maturity in 1-3 years and live 1-8 and 3-7 years, respectively.
\end{abstract}

Keywords: age structure, Masoala, natural history museums, skeletochronology, vertebrate collections. 


\begin{abstract}
Resumo
Longevidade comparada e idade da maturidade sexual em doze anuros dos gêneros Boophis, Gephyromantis e Mantidactylus (Anura: Mantellidae) da floresta tropical de Madagascar. Apresentamos aqui dados sobre a idade na maturidade sexual e longevidade para algumas espécies de Mantellidae dos gêneros Boophis, Gephyromantis e Mantidactylus que habitam a floresta tropical de baixa altitude de Masoala (nordeste de Madagascar). Contagens de linhas de crescimento (LAGs) foram utilizadas para calcular a longevidade dessas espécies; esses dados contribuem para avaliações do nível de ameaça desses anuros. Boophis inclui espécies de médio a grande porte (SVL $=30-65$ $\mathrm{mm}$ ) que atingem a maturidade sexual em 1-3 anos e vivem de 3-9 anos (i.e., longevidade média). Mantidactylus e Gephyromatis incluem espécies de pequeno a grande porte (SVL $=22-107$ e 35-49 $\mathrm{mm}$, respectivamente) que atingem maturidade sexual em 1-3 anos e vivem de 1-8 e 3-7 anos, respectivamente.
\end{abstract}

Palavras-chave: coleções de vertebrados, estrutura etária, esqueletocronologia, Masoala, museus de história natural.

\section{Introduction}

The ongoing discovery of new amphibian species in Madagascar represents a great conservation challenge for this biodiversity hotspot. Currently, 310 species are formally recognized, with at least another 200 candidate species yet to be described (Glaw and Vences 2007, Vieites et al. 2009, Perl et al. 2014). Most of these anurans are threatened by a series of factors that include habitat loss and degradation, emergent pathogens, exotic species introductions, and collection for food and pet trade (Andreone et al. 2005, 2006, 2016). Despite the paramount importance to assess species vulnerability and to draw conservation redlists (Andreone and Luiselli 2003, Andreone et al. 2016), the ecology of most anurans in Madagascar is still understudied. Many species are known only from their types (i.e., holotypes and paratypes), and for several taxa, little or nothing is known about their natural history, such as food and habitat preferences, fecundity, and longevity. This is not surprising given the remote distributions of these anurans and the limited funding available for amphibian ecological studies in contrast to biodiversity assessments and relatively rapid bio-molecular analyses.
Here we provide new ecological data on three understudied anuran genera of the family Mantellidae based on integration of published literature, field observation, museum specimens, and skeletochronology. We provide data on age at maturity and longevity for 12 species that inhabit the low-elevation Masoala rainforest of northeastern Madagascar, as follow: six species of Boophis Tschudi, 1838 (B. anjanaharibeensis Andreone, 1996; B. axelmeyeri Vences, Andreone, and Vieites, 2005; B. englaenderi Glaw and Vences, 1994; B. roseipalmatus Glaw, Köhler, De la Riva, Vieites, and Vences, 2010; B. tephraeomystax (Duméril, 1853); and B. aff. reticulatus); two species of Gephyromantis Methuen, 1920 (G. luteus [Methuen and Hewitt, 1913] and G. redimitus [Boulenger, 1889]); and four species of Mantidactylus Boulenger, 1895 (M. aff. betsileanus "Andranofotsy" Ca26; M. aff. femoralis "Marojejy" Ca43; M. aff. grandidieri "North"; and $M$. aff. zipperi). The candidate species names follow the indication and nomenclature provided by Glaw and Vences (2007) and Vieites et al. (2009).

\section{Materials and Methods}

This study is based on the skeletochronological analysis of preserved museum specimens 
(Appendix I) and is limited to the species for which at least four specimens were available. The taxonomic determination of these species is based on morphology and molecular tools (barcoding). Data presented here were obtained using bones (usually the phalanx of the third toe) or phalanges taken from specimens housed in the Parc Botanique et Zoologique de Tsimbazaza, Antananarivo (Madagascar, PBZT) and in the Museo Regionale di Scienze Naturali, Torino (Italy, MRSN). Franco Andreone and collegues collected the specimens during surveys in the Masoala rainforests in November and December of 1998 and 1999; these are preserved in 65\% ethanol. We sexed specimens by comparing secondary sexual characters (i.e., presence of nuptial pad and vocal sacs in Boophis, presence of femoral glands and vocal sacs in Mantidactylus and Gephyromantis) and/or looking at gonads by making a small slit in the venter. We classified individuals that lacked evident secondary sexual characters as juveniles. We measured specimens (snout-vent length, SVL) to the nearest $0.1 \mathrm{~mm}$ with a dial calipers.

Skeletochronology was performed following standard protocols already used in studies of other Malagasy species (e.g., Guarino et al. 1998, Andreone et al. 2002), as follows. We immersed bones in 5\% nitric acid for $2 \mathrm{hr}$ and then cross-sectioned the bones at $16 \mu \mathrm{m}$ with a cryostat and stained them in Ehrlich's haematoxylin for about $15 \mathrm{~min}$. Two independent researchers examined the sections and counted the lines of arrested growth (LAGs) with a light microscope. We estimated age by counting LAGs. These lines are the result of alternating cold-warm and/or wet-dry seasons, and usually indicate yearly rhythms (Castanet 1975). To estimate age at sexual maturity, we adopted the criterion of LAG rapprochement as proposed by Kleineberg and Smirina (1969), where slower growth is related to an adult age. We identified LAGs affected by bone remodelling using osteometrical analysis based on the youngest specimen available (Tessa et al. 2007). False lines, intraseasonal, incomplete, and undefined
LAGs cause by growth interruption (sensu Castanet et al. 1993) were identifed.

\section{Results}

The species of Boophis examined have a wide range of body sizes; $B$. englaenderi has a maximum SVL of $33.49 \mathrm{~mm}$, whereas that of $B$. roseipalmatus is $64.82 \mathrm{~mm}$. Both species of Gephyromantis are medium-sized (maximum SVL $=48.70 \mathrm{~mm}$ ), Mantidactylus contains relatively small species ( $M$. aff. betsileanus "Andranofotsy" Ca26; maximum SVL $=32.83$ $\mathrm{mm}$ ), as well as large ones (M. aff. grandidieri "North"; maximum SVL = 107.10 mm; Table 1).

We detected sharp and evident LAGs in all species that we examined (Table 1, Figure 1), thereby indicating seasonality in the Masoala rainforest, despite an expected climatic homogeneity throughout the year. We think that this reflects climatic fluctuations and/or food availability. The bone sections of Boophis appeared rather homogenous, with a contrasted resorption line (RL) separating the endosteal from periosteal bones. The two layers were formed by lamellar and pseudolamellar bone tissue. Resorption affected the first $(29 \%)$ and occasionally $(6 \%)$ the second LAG. LAGs were evident in periosteal bone, and more extensive than in the endosteal bone. False lines were present in $24 \%$ of the sections examined. Mean age was around 4 years (range 2-9), only slightly less that of B. tsilomaro (Andreone et al. 2002) and close to $B$. williamsi (Andreone et al. 2014). Species of Mantidactylus and Gephyromantis species had clearly visible LAGs in the periosteal bone, which is separated from the endosteal bone by RL. The presence of false and double lines was rare (4\% of the examined sections). Resorption affected partially the first and innermost LAG (16\%). Small- and mediumsized species $($ SVL $=20-60 \mathrm{~mm}$ ) had a mean age between 4 and 6 years, similar to that of Bohemantis microtympanum (Angel, 1935), a genus recently separated from Mantidactylus. Mantidactylus aff. grandidieri "North," the largest 
species examined (SVL $>100 \mathrm{~mm}$ ), had the highest LAGs number (8), with sexual maturity reached at a maximum of 5 years.

Most of the species of Boophis reach sexual maturity after 1-2 years; however, in $B$. englaenderi, males seemed to reach sexual maturity in 2 years and females in 3 years, and in B. tephraeomystax, females reached sexual maturity in 3 years. In the species of Mantidactylus, sexual maturity usually is reached in 3 years in females and in 2 years in males; $M$. aff. grandidieri "North," is an exception because some males and females may reach maturity in 4 and 5 years, respectively. In Gephyromantis, sexual maturity usually occurs in 2 years in both sexes, but some female $G$. redimitus reach sexual maturity in 3 years and some male $G$. redimitus in 1 year (Table 1).

\section{Discussion}

As shown in several other species (Guarino et al. 1998, 2003, 2008, Andreone et al. 2002, 2011, 2014, Tessa et al. 2007, 2011, Jovanovic and Vences 2010), our data demonstrate the value of skeletochronology as a tool in the study of anurans in tropical and subtropical regions such as Madagascar. Because LAGs were detected in all of the species examined (Figure 1), it seems that seasonality characterizes the forests of Masoala Peninsula, despite the low altitude. In other frogs studied, such as the large, iconic, red microhylid, Dyscophus antongilii Grandidier, 1877 that also lives in and around Masoala, LAGs were not visible; this absence was thought to indicate a lack of seasonality at the low altitude and suburban studied site (Tessa et al. 2007). However, D. antongilii usually inhabits open areas, breeding in ponds and ditches in the town of Maroantsetra, which is warm throughout the year; thus, seasonality probably is less marked in this species than in forest-dwelling species.

The varying life spans of the three genera may reflect differing habitat adaptations. All the species of Mantidactylus that we sampled are terrestrial or scansorial and diurnal/nocturnal, whereas the species of Gephyromantis are nocturnal, and arboreal or semi-arboreal, and the species of Boophis are nocturnal and arboreal. However, there is substantial intrageneric variation in size and age data. In general, smallersized species do not live as long and reach sexual maturity earlier than larger-sized species of larger sizes. Mantidactylus aff. grandidieri "North" reaches sexual maturity later than do other species, despite having comparable longevity. Mantidactylus aff. grandidieri "North" is edible (Andreone et al. 2012), and the oldest and largest individuals frequently are collected for consumption. This may have a bearing on our results and requires additional study.

The value of specimens housed in natural history collections to conservation assessments cannot be underestimated. There are specimens other than type series housed in major collections, and these can be used to study diet (either through dissection or using non-invasive and non-destructive; e.g., Fortuny et al. 2015, Scherz et al. 2016), to analyze the pattern of prevalence, intensity, and distribution of some pathogens (e.g., for the occurrence of emerging infective diseases: Zhu et al. 2014), for genetic purposes (e.g., Wandeler et al. 2007), for anatomical preparations and also for determining age at maturity, and species longevity (Suarez and Tsutsui 2004, Tessa et al. 2011). As demonstrated in other studies, the use of preserved specimens for skelectrochronology is possible in amphibians from Madagascar (Guarino et al. 2010, Andreone et al. 2011). These data, combined with genetic data and data collected in the field, represent a storehouse of information vital to developing sensible conservation measures (e.g., defininition of quotas of collectable individuals and inform researchers about the ecological sensitivities of understudied amphibians (Andreone et al. 2016).

\section{Acknowledgments}

We are indebted to the Parc Botanique et Zoologique de Tsimbazaza and the Direction des 

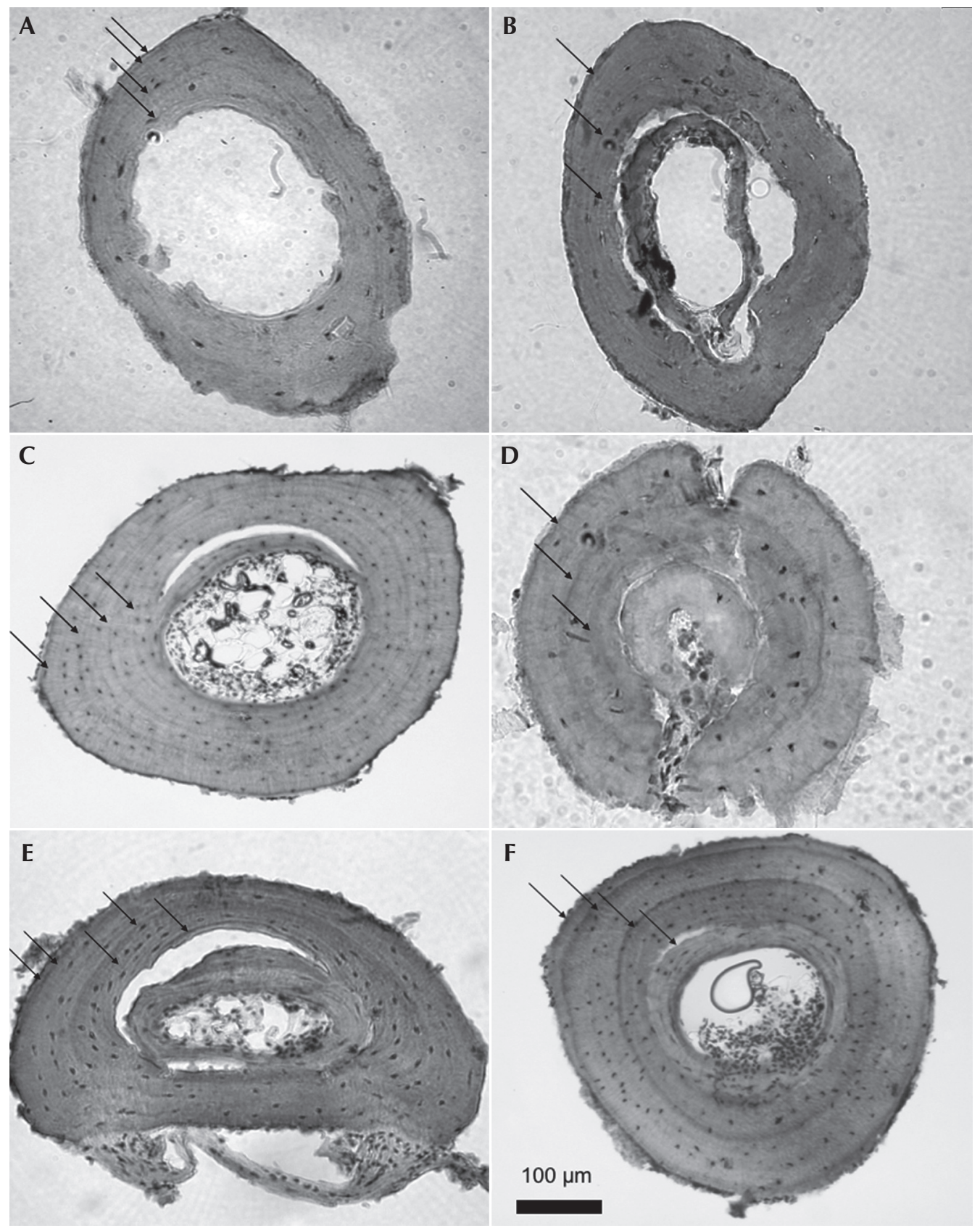

Figure 1. Histological sections of the specimens examined. Arrows indicate the lines of arrested growth (LAGs). (A) Mantidactylus aff. femoralis "Marojejy" Ca43, MRSN A3716, male, 4 LAGs, SVL $=35.65 \mathrm{~mm}$. (B) Mantidactylus aff. zipperi, MRSN A3711, male, 3 LAGs, SVL $=29.21 \mathrm{~mm}$. (C) Boophis axelmeyeri, PBZT, male, 4 LAGs (the two outer lines converge for the most part before to split), SVL $=65.10 \mathrm{~mm}$. (D) $B$. englaenderi, MRSN A3060, male, 3 LAGs, SVL $=32.60$ mm. (E) B. roseipalmatus, MRSN A5112, female, 5 LAGs, SVL $=52.18 \mathrm{~mm}$. (F) Gephyromantis redimitus, MRSN A4061, male, 4 LAGs, SVL $=43.82 \mathrm{~mm}$. 
Table 1. Data on sex, body size (SVL, mm), longevity (LAGs number, corresponding to years) and age (years) at sexual maturity in the analysed species.

\begin{tabular}{|c|c|c|c|c|}
\hline \multirow{2}{*}{ Species } & \multirow{2}{*}{$\begin{array}{l}\text { Sex (number } \\
\text { of examined } \\
\text { individuals) }\end{array}$} & SVL & LAGs & $\begin{array}{l}\text { Age at sexual } \\
\text { maturity }\end{array}$ \\
\hline & & $\begin{array}{c}\text { mean } \pm S D \\
\quad(\text { range })\end{array}$ & $\begin{array}{c}\text { mean } \pm S D \\
\quad(\text { range })\end{array}$ & $\begin{array}{c}\text { mean } \pm S D \\
\text { (range) }\end{array}$ \\
\hline \multirow{2}{*}{ Boophis anjanaharibeensis } & $\begin{array}{c}\text { Males } \\
(3)\end{array}$ & $\begin{array}{c}34.34 \pm 0.24 \\
(34.08-34.39)\end{array}$ & $\begin{array}{c}3.67 \pm 0.58 \\
(3-4)\end{array}$ & $\begin{array}{c}1.67 \pm 0.58 \\
(1-2)\end{array}$ \\
\hline & $\begin{array}{c}\text { Juveniles } \\
\text { (1) }\end{array}$ & $\begin{array}{c}20.25 \\
(-)\end{array}$ & $\begin{array}{c}0 \\
(-)\end{array}$ & $(-)$ \\
\hline \multirow{2}{*}{ Boophis axelmeyeri } & $\begin{array}{l}\text { Males } \\
(4)\end{array}$ & $\begin{array}{c}47.44 \pm 2.30 \\
(45.01-50.55)\end{array}$ & $\begin{array}{c}6.75 \pm 1.26 \\
(5-8)\end{array}$ & $\begin{array}{c}1 \pm 0 \\
(1)\end{array}$ \\
\hline & $\begin{array}{c}\text { Females } \\
(2)\end{array}$ & $\begin{array}{c}53.55 \pm 7.70 \\
(48.10-59.00)\end{array}$ & $\begin{array}{c}7.50 \pm 2.12 \\
(6-9)\end{array}$ & $\begin{array}{c}1 \pm 0 \\
(1)\end{array}$ \\
\hline \multirow{2}{*}{ Boophis englaenderi } & $\begin{array}{c}\text { Males } \\
(3)\end{array}$ & $\begin{array}{c}32.02 \pm 1.83 \\
(29.96-33.49)\end{array}$ & $\begin{array}{c}3.00 \\
(-)\end{array}$ & $\begin{array}{c}2.33 \pm 0.57 \\
(2-3)\end{array}$ \\
\hline & $\begin{array}{c}\text { Females } \\
\text { (1) }\end{array}$ & $\begin{array}{c}31.01 \\
(-)\end{array}$ & $\begin{array}{c}4.00 \\
(-)\end{array}$ & $\begin{array}{l}3 \\
(-)\end{array}$ \\
\hline \multirow{2}{*}{ Boophis roseipalmatus } & $\begin{array}{c}\text { Males } \\
(3)\end{array}$ & $\begin{array}{c}54.70 \pm 3.23 \\
(52.18-58.35)\end{array}$ & $\begin{array}{c}6.00 \pm 1.00 \\
(5-7)\end{array}$ & $\begin{array}{c}1 \pm 0 \\
(1)\end{array}$ \\
\hline & $\begin{array}{c}\text { Females } \\
\text { (3) }\end{array}$ & $\begin{array}{c}64.08 \pm 0.65 \\
(63.58-64.82)\end{array}$ & $\begin{array}{c}7.00 \pm 1.00 \\
(6-8)\end{array}$ & $\begin{array}{c}1.33 \pm 0.58 \\
(1-2)\end{array}$ \\
\hline Boophis aff. reticulatus & $\begin{array}{c}\text { Males } \\
(4)\end{array}$ & $\begin{array}{c}35.46 \pm 1.37 \\
(34.08-37.09)\end{array}$ & $\begin{array}{c}5.50 \pm 0.58 \\
(5-6)\end{array}$ & $\begin{array}{c}1.75 \pm 0.50 \\
(1-2)\end{array}$ \\
\hline \multirow{2}{*}{ Boophis tephraeomystax } & $\begin{array}{c}\text { Males } \\
(2)\end{array}$ & $\begin{array}{c}35.68 \pm 4.61 \\
(32.42-38.94)\end{array}$ & $\begin{array}{c}4.50 \pm 0.70 \\
(4-5)\end{array}$ & $\begin{array}{c}1 \pm 0 \\
(1)\end{array}$ \\
\hline & $\begin{array}{c}\text { Females } \\
(6)\end{array}$ & $\begin{array}{c}42.84 \pm 5.35 \\
(33.86-47.47)\end{array}$ & $\begin{array}{c}5.33 \pm 1.37 \\
(3-7)\end{array}$ & $\begin{array}{l}2 \pm 0 \\
(1-3)\end{array}$ \\
\hline \multirow{2}{*}{$\begin{array}{l}\text { Mantidactylus aff. betsileanus } \\
\text { "Andranofotsy" Ca26 }\end{array}$} & $\begin{array}{l}\text { Males } \\
(7)\end{array}$ & $\begin{array}{c}24.76 \pm 2.37 \\
(22.38-28.80)\end{array}$ & $\begin{array}{c}3.28 \pm 0.49 \\
(3-4)\end{array}$ & $\begin{array}{c}2.14 \pm 0.38 \\
(2-3)\end{array}$ \\
\hline & $\begin{array}{l}\text { Females } \\
(2)\end{array}$ & $\begin{array}{l}29.66 \pm 4.47 \\
(26.50-32.83)\end{array}$ & $\begin{array}{c}4.50 \pm 0.71 \\
(4-5)\end{array}$ & $\begin{array}{l}3 \pm 0 \\
(3)\end{array}$ \\
\hline \multirow{2}{*}{$\begin{array}{l}\text { Mantidactylus aff. femoralis } \\
\text { "Marojejy" Ca43 }\end{array}$} & $\begin{array}{c}\text { Males } \\
(5)\end{array}$ & $\begin{array}{c}34.41 \pm 2.06 \\
(31.38-37.16)\end{array}$ & $\begin{array}{c}3.00 \pm 0.71 \\
(2-4)\end{array}$ & $\begin{array}{c}2 \pm 0 \\
(2)\end{array}$ \\
\hline & $\begin{array}{l}\text { Females } \\
\text { (4) }\end{array}$ & $\begin{array}{c}49.15 \pm 7.76 \\
(41.53-57.52)\end{array}$ & $\begin{array}{c}4.75 \pm 0.96 \\
(4-6)\end{array}$ & $\begin{array}{l}3 \pm 0 \\
(3)\end{array}$ \\
\hline \multirow{3}{*}{$\begin{array}{l}\text { Mantidactylus aff. grandidieri } \\
\text { "North" }\end{array}$} & $\begin{array}{l}\text { Males } \\
(8)\end{array}$ & $\begin{array}{l}73.66 \pm 12.43 \\
(47.00-83.40)\end{array}$ & $\begin{array}{c}5.75 \pm 1.67 \\
(3-8)\end{array}$ & $\begin{array}{c}2.86 \pm 0.26 \\
(2-4)\end{array}$ \\
\hline & $\begin{array}{c}\text { Females } \\
\text { (2) }\end{array}$ & $\begin{array}{c}97.30 \pm 13.86 \\
(87.50-107.10)\end{array}$ & $\begin{array}{l}5.50 \pm 0.71 \\
(5-6)\end{array}$ & $\begin{array}{l}4 \pm 1 \\
(3-5)\end{array}$ \\
\hline & $\begin{array}{l}\text { Juveniles } \\
\qquad(2)\end{array}$ & $\begin{array}{l}45.45 \pm 12.09 \\
(36.90-54.00)\end{array}$ & $\begin{array}{l}2.00 \pm 1.41 \\
(1-3)\end{array}$ & - \\
\hline
\end{tabular}


Table 1. Continued.

\begin{tabular}{|c|c|c|c|c|}
\hline \multirow{2}{*}{ Species } & \multirow{2}{*}{$\begin{array}{l}\text { Sex (number } \\
\text { of examined } \\
\text { individuals) }\end{array}$} & SVL & LAGs & $\begin{array}{c}\text { Age at sexual } \\
\text { maturity }\end{array}$ \\
\hline & & $\begin{array}{c}\text { mean } \pm \text { SD } \\
\quad(\text { range })\end{array}$ & $\begin{array}{c}\text { mean } \pm \text { SD } \\
\quad(\text { range })\end{array}$ & $\begin{array}{c}\text { mean } \pm \text { SD } \\
\quad(\text { range })\end{array}$ \\
\hline \multirow{2}{*}{ Mantidactylus aff. zipperi } & $\begin{array}{l}\text { Males } \\
(4)\end{array}$ & $\begin{array}{c}26.61 \pm 2.50 \\
(24.44-29.21)\end{array}$ & $\begin{array}{c}3.50 \pm 1.29 \\
(2-5)\end{array}$ & $\begin{array}{c}1.25 \pm 0.25 \\
(1-2)\end{array}$ \\
\hline & $\begin{array}{c}\text { Females } \\
\text { (3) }\end{array}$ & $\begin{array}{c}29.86 \pm 3.68 \\
(26.19-33.56)\end{array}$ & $\begin{array}{c}4.00 \pm 3.68 \\
(3-5)\end{array}$ & $\begin{array}{c}2.67 \pm 0.33 \\
(2-3)\end{array}$ \\
\hline \multirow{2}{*}{ Gephyromantis luteus } & $\begin{array}{c}\text { Males } \\
(3)\end{array}$ & $\begin{array}{c}37.22 \pm 2.61 \\
(34.56-46.17)\end{array}$ & $\begin{array}{c}3.67 \pm 2.40 \\
(3-5)\end{array}$ & $\begin{array}{c}2 \pm 0 \\
(2)\end{array}$ \\
\hline & $\begin{array}{c}\text { Females } \\
(2)\end{array}$ & $\begin{array}{c}44.32 \pm 2.61 \\
(42.48-46.17)\end{array}$ & $\begin{array}{c}4.00 \\
(-)\end{array}$ & $\begin{array}{c}2 \pm 0 \\
(2)\end{array}$ \\
\hline \multirow{3}{*}{ Gephyromantis redimitus } & $\begin{array}{l}\text { Males } \\
(14)\end{array}$ & $\begin{array}{c}46.44 \pm 2.01 \\
(43.80-48.40)\end{array}$ & $\begin{array}{c}4.50 \pm 1.22 \\
(3-7)\end{array}$ & $\begin{array}{c}1.54 \pm 0.14 \\
(1-2)\end{array}$ \\
\hline & $\begin{array}{c}\text { Females } \\
\text { (3) }\end{array}$ & $\begin{array}{c}47.18 \pm 1.37 \\
(46.04-48.70)\end{array}$ & $\begin{array}{c}4.33 \pm 0.58 \\
(4-5)\end{array}$ & $\begin{array}{c}2.67 \pm 0.33 \\
(2-3)\end{array}$ \\
\hline & $\begin{array}{c}\text { Juveniles } \\
\text { (1) }\end{array}$ & $\begin{array}{c}17.58 \\
(-)\end{array}$ & $\begin{array}{l}0 \\
-\end{array}$ & - \\
\hline
\end{tabular}

Eaux et Forêts at Nanisana (Antananarivo) for permissions to visit the protected area of Masoala and for collecting the voucher specimens. The work of AC was supported by an Investigador FCT (IF) grant from the Portuguese "Fundação para a Ciência e a Tecnologia" (IF/00209/2014), funded by Programa Operacional Potencial Humano (POPH)—Quadro de Referência Estratégico Nacional (QREN) from the European Social Fund.

\section{References}

Andreone, F. and L. M. Luiselli. 2003. Conservation priorities and potential threats influencing the hyperdiverse amphibians of Madagascar. Italian Journal of Zoology 70: 53-63.

Andreone, F., M. Vences, F. M. Guarino, F. Glaw, and J. E. Randrianirina. 2002. Natural history and larval morphology of Boophis occidentalis (Anura: Mantellidae: Boophinae) provide new insights into the phylogeny and adaptive radiation of endemic Malagasy frogs. Journal of Zoology, London 257: 425-438.
Andreone, F., J. E. Cadle, N. Cox, F. Glaw, R. A. Nussbaum, C. J. Raxworthy, S. N. Stuart, D. Vallan, and M. Vences. 2005. Species review of amphibian extinction risks in Madagascar: conclusions from the global amphibian assessment. Conservation Biology 19: 1790-1802.

Andreone, F., V. Mercurio, and F. Mattioli. 2006. Between environmental degradation and international pet trade: conservation strategies for the threatened amphibians of Madagascar. Natura 95: 81-96.

Andreone, F., C. Giacoma, F. M. Guarino, V. Mercurio, and G. Tessa. 2011. Age profile in nine Mantella poison frogs from Madagascar, as revealed by skeletochronological analyses. Alytes 27: 73-84.

Andreone, F., A. I. Carpenter, J. Copsey, A. Crottini, G. Garcia, R. K. B. Jenkins, J. Köhler, N. H. C. Rabibisoa, H. Randriamahazo, and C. J. Raxworthy. 2012. Saving the diverse Malagasy amphibian fauna: where are we four years after implementation of the Sahonagasy Action Plan? Alytes 29: 44-58.

Andreone, F., A. Crottini, F. C. E. Rabemananjara, J. E. Randrianirina, T. J. Razafindrabe, and G. Tessa. 2014. Age structure, population estimate and Bd-status of two Critically Endangered frogs from the Ankaratra Massif (Madagascar), Boophis willliamsi and Mantidactylus pauliani (Amphibia: Mantellidae). Pp. 17-29 in M. 
Capula and C. Corti (eds), Scripta Herpetologica. Studies on Amphibians and Reptiles in Honour of Benedetto Lanza. Latina. Monografie Societas Herpetologica Italica III, Edizioni Belvedere.

Andreone, F., J. S. Dawson, F. C. E. Rabemananjara, N. H. C. Rabibisoa, and T. F. Rakotonanahary (eds). 2016. New Sahonagasy Action Plan 2016-2020. Turin. Museo Regionale di Scienze Naturali and Amphibian Survival Alliance. 46 pp.

Castanet, J. 1975. Quelques observations sur la présence et la structure des marques squelettiques de croissance chez les amphibiens. Bulletin de la Société Zoologique de France 100: 603-620.

Castanet, J., H. Francillon-Vieillot, F. J. Meunier, and A. de Ricqlès. 1993. Bone and individual aging. Pp. 245-283 in B. K. Hall (ed.), Bone, Volume 7: Bone Growth. Boca Raton. CRC Press.

Fortuny, J., J. Marcé-Nogué, E. Heiss, M. Sanchez, L. Gil, and À. Galobart. 2015. 3D Bite modeling and feeding mechanics of the largest living amphibian, the Chinese Giant Salamander Andrias davidianus (Amphibia: Urodela). PLOS ONE 10: e0121885.

Glaw, F. and M. Vences. 2007. A Field Guide to the Amphibians and Reptile of Madagascar. $3^{\text {th }}$ edition. Cologne. Vences and Glaw Verlag GbR. 496 pp.

Guarino, F. M., F. Andreone, and F. Angelini. 1998. Growth and longevity by skeletochronological analysis in Mantidactylus microtympanum, a rain-forest anuran from southern Madagascar. Copeia 1998: 194-198.

Guarino, F. M., S. Lunardi, M. Carlomagno, and S. Mazzotti. 2003. A skeletochronological study of growth, longevity, and age at sexual maturity in a population of Rana latastei (Amphibia, Anura). Journal of Bioscience 28: $775-782$.

Guarino, F. M., M. Sacco, G. Tessa, and F. Andreone. 2008. Short life span of two charismatic Mantella species: agestructure in the critically endangered $M$. cowani and in the syntopic M. baroni. Pp. 265-276 in F. Andreone (ed.), Conservation Strategy for the Amphibians of Madagascar. Turin. Monografie 45, Museo Regionale di Scienze Naturali di Torino.

Guarino, F. M., G. Tessa, V. Mercurio, and F. Andreone. 2010. Rapid sexual maturity and short life span in the blue-legged frog and the rainbow frog from the arid Isalo Massif, southern-central Madagascar. Zoology 113: $378-384$.
Kleineberg, S. E. and E. M. Smirina. 1969. A contribution to the method of age determination in amphibians. Zoologicheskiy Zhurnal 48: 1090-1094.

Jovanovic, O. and M. Vences. 2010. Skeletochronological analysis of age structure in populations of four species of Malagasy poisonous frogs, genus Mantella. AmphibiaReptilia 31: 553-557.

Perl, R. G. B., Z. T. Nagy, G. Sonet, F. Glaw, K. C. Wollenberg, and M. Vences. 2014. DNA barcoding Madagascar's amphibian fauna. Amphibia-Reptilia 35: 197-206.

Scherz, M. D., M. Vences, A. Rakotoarison, F. Andreone, J. Köhler, F. Glaw, and A. Crottini. 2016. Reconciling molecular phylogeny, morphological divergence and classification of Madagascan narrow-mouthed frogs (Amphibia: Microhylidae). Molecular Phylogenetics and Evolution 100: 372-381.

Suarez, A. V. and N. D. Tsutsui. 2004. The value of museum collections for research and society. BioScience 54: 6674.

Tessa, G., F. M. Guarino, C. Giacoma, F. Mattioli, and F. Andreone. 2007. Longevity and body size in three populations of Dyscophus antongilii (Anura, Microhylidae), the tomato frog from north-eastern Madagascar. Acta Herpetologica 2: 139-146.

Tessa, G., F. M. Guarino, J. E. Randrianirina, and F. Andreone. 2011. Age structure in the false tomato frog Dyscophus guineti from eastern Madagascar compared to the closely related $D$. antongilii (Anura, Microhylidae). African Journal of Herpetology 60: 84-88.

Vieites, D. R., K. C. Wollenberg, F. Andreone, J. Köhler, F. Glaw, and M. Vences. 2009. Vast underestimation of Madagascar's biodiversity evidenced by an integrative amphibian inventory. Proceedings of the National Academy of Sciences of the United States of America 106: $8267-8272$.

Wandeler P., P. E. A. Hoeck, and L. F. Keller. 2007. Back to the future: museum specimens in population genetics. Trends in Ecology and Evolution 22: 634-642.

Zhu, W., C. Bai, S. Wang, C. Soto-Azat, X. Li, X. Liu, and Y. Li. 2014. Retrospective survey of museum specimens reveals historically widespread presence of Batrachochytrium dendrobatidis in China. EcoHealth 11: 241-250.

Editor: Tim Halliday 
Appendix I. List of specimens used for skeletochronological analysis.

Abbreviations: MRSN, specimens housed in the Museo Regionale di Scienze Naturali, Torino; PBZT, specimens housed in the Parc Botanique et Zoologique de Tsimbazaza, Antananarivo.

MAntellidae Boophinae: Boophis anjanaharibeensis Andreone, 1996 (MRSN A4433, A4391, A4373, A4374); Boophis axelmeyeri Glaw \& Vences, 1997 (MRSN A3117, A3120, A4114, A4115, A4252, A4321); Boophis englaenderi Glaw \& Vences, 1994 (MRSN A4105, A4106, A4354, A4408); Boophis roseipalmatus Glaw et al., 2010 (MRSN A4293-4295, A4400, A4299, A3260); Boophis aff. reticulatus (MRSN A4308, A4309, A4242, A4243); Boophis tephraeomystax (Duméril, 1853) (MRSN A4126, A4127, A4130-4135).

Mantellidae Mantellinae: Gephyromantis luteus (Methuen \& Hewitt, 1913) (MRSN A3229, A3786, A3787, A3780, A3230); Gephyromantis redimitus (Boulenger, 1889) (MRSN A3163, A4010, A3161, A4061, A3829, A4060, A4067, 11 phalanges, PBZT); Mantidactylus aff. betsileanus "Andranofotsy" Ca26 (MRSN A3680, A3677, A3726, A3727, A3731, A3798, A3734, A3730, A3678); Mantidactylus aff. femoralis "Marojejy" Ca43 (MRSN A 3713-3716, A3759, A3173-3175); Mantidactylus aff. grandidieri "North" (12 phalanges, PBZT); Mantidactylus aff. zipperi (MRSN A37103712, A3741, A3745, A3748, A3752). 